\title{
First Record of Lobothorax Typus from Odisha Coast, India, with Molecular Characterisation and Observation of its Biphasic Moulting
}

Jaya Kishor Seth ( $\square$ jkseth52@gmail.com )

Berhampur University https://orcid.org/0000-0002-1331-5971

Swarup Ranjan Mohanty

EBRC/ZSI

Amit Kumar Behera

Berhampur University

Laxman Kumar Murmu

Berhampur University

Anil Mohapatra

EBRC/ZSI

\section{Research Article}

Keywords: Cymothoidae, COI genes, K2P distance, ML tree, monophyletic

Posted Date: March 25th, 2021

DOl: https://doi.org/10.21203/rs.3.rs-348486/v1

License: (a) (1) This work is licensed under a Creative Commons Attribution 4.0 International License. Read Full License 


\section{Abstract}

Two distinct morphologies of Cymothoidae isopod, Lobothorax typus were collected from the marine water of Bay of Bengal, Goapalpur-on-Sea as the first record of this parasite from coastal water of Odisha, India. All specimens were found attached to the buccal region of different individuals of the same host fish Trichiurus lepturus. With the aid of $\mathrm{COI}$ gene sequencing and morphological analysis, the individuals were found to be conspecific. The most prominent variation among the two morphologies includes the size of 5th pereonite and pleon length to total body length ratio. These variations are as a result of the biphasic moulting process. Maximum Likelihood (ML) tree analysis based on $\mathrm{COI}$ gene sequences concluded the monophyletic taxonomy of different buccal attaching genera under the family Cymothoidae which is in congruence with their morphological divergence.

\section{Introduction}

The study of the representatives of the family Cymothoidae are important as they are obligate ectoparasites to many fresh, brackish and marine fish species. Most of these parasites are show a high scale of the site and host-specific (Ravichandran et al. 2019). These parasites are known to cause a wide range of damaging effects to many host fish species which includes tissues damage, varieties of wounds, growth inhibition, behavioural changes, impacting the reproductive potential, even cause death to the small fishes; thereby impacting the fisheries resources (Rameshkumar et al.2013; Kumar et al .2015; Aneesh et al. 2018, 2019; Seth et al. 2020 a, b). Indian water is known to harbour 48 valid species belonging to 16 genera under the family Cymothoidae. Most of the studies on species of the family Cymothoidae in Indian water are confined to Southern Indian coast (Ravichandran et al. 2019). The information on the isopods of the family Cymothoidae from the coastal water of Odisha, India is scanty and requires a comprehensive longterm study to come up with an updated data (Seth et al. 2020 a, b).

The representatives of genera: Cymothoa Fabricius, 1793, Ceratothoa Dana, 1852, Cinusa Schiödte and Meinert, 1884, Glossobius Schiödte and Meinert, 1883, Lobothorax Bleeker, 1857, and Smenispa Özdikem, 2009 of the family: Cymothoidae are known to cause infection in the buccal cavity of the host fishes (Aneesh et al.2018).The genus Lobothorax of the family: Cymothoidae is consisting of three species viz., $L$. aurita (Schiöedte \& Meinert, 1883), L. laevis Richardson, 1910, and L. typus Bleeker, 1857. The species L. typus is known to occur from the South-eastern Asia region: Java, Jakarta, Indonesia (as Batavia Bleeker 1857, Schiöedte and Meinert 1883), East Malaysia (Kumar et al. 2015), and South China Sea (Yu \& Bruce 2006). In India, it is documented from the South-eastern coast (Rameshkumar et al. 2013; Ravichandran et al. 2019). The species $L$. aurita and L. laevis are known to occur from the Philippines (Schiöedte and Meinert 1883; Richardson, 1910). The species L. typus is known to cause infection in the buccal region of the host fish species i.e. Trichiurus lepturus (Ravichandran et al. 2019) and Lepturacanthus savala (Yu and Bruce 2006). The details taxonomic features of L. typus was given by Yu and Bruce (2006). The present record of the species L. typus from water of Bay of Bengal, Gopalpur-on-Sea is the first material evidence of this isopod parasite from the Odisha coast, India. 
Study of life cycle especially moulting in isopods is very important as it affects growth, development and reproduction. The biphasic moulting is generally observed in isopods in which posterior body part moult before the anterior half and break between the two halves at the junction between the 4th and 5th pereonites. The moulting in isopods has four stages: intermoult, premoult, ecdysis and postmoult. The changes, which are occurring in different stages of moulting can be observed from the observation of their appendages. In the female, moulting take place by the shedding of old oostegites (brood plates). One pair of oostegites are shed through the ecdysis of the posterior half; followed by the shedding of remaining three pair of oostegites through the subsequent ecdysis (Aneesh and Kappalli 2020; Sahadevan 2019). This manuscript only provides a note on the observation on the variation among the two distinct morphologies of the isopod L. typus in terms of 5 th pereonite and pleon to total body length ratio, which are the results of the biphasic moulting.

In the recent decades, molecular identification based on cytochrome c oxidase subunit 1 (CO1) of mitochondrial genome has been successfully used in taxonomic studies, description of various species and diversity assessments of Crustaceans (Raupach et al. 2015). Due to intra and inter specific variations, species of the family Cymothoidae are known to exhibit high degree of polymorphism (Bruce 1981; Smit et al. 2014). In this juncture, molecular characterisation based on conserved region like COI gene is very useful in species level delineation and helpful in understating the phylogeny of the species of the family Cymothoidae. Till date there is no such report on the molecular characterisation of the COI gene of the species $L$. typus; the present report on the molecular characterisation of this species will be very useful to supplement its morphological data and intra-specific variation found in the species. The present manuscript also describes the phylogenetic relationship among the buccal attaching representing belonging to the family: Cymothoidae through Kimura 2 Parameter (K2P) distance and ML tree analysis based on $\mathrm{COI}$ genes of this parasite and other buccal attaching parasites obtained from the NCBI database.

\section{Materials And Methods}

The representatives of the host $T$. lepturus were collected during gill net operation in December 2018 from the water of Bay of Bengal, Gopalpur-on-Sea (19 $\left.15^{\prime} 43.22^{\prime \prime} \mathrm{N}, 84^{\circ} 54^{\prime} 50.01^{\prime \prime} \mathrm{E}\right)$, Odisha coast, India. The host fish species was identified as per the standard keys and description provided in Fish Base (Forese and Pauly 2018). The isopods of the family Cymothoidae were gently removed from their respective attachment sites of the host fish species and kept in $70 \%$ alcohol. The isopod parasites were identified after following the features as described by Yu and Bruce (2006) and Ravichandran et al. (2019). All the parasites and hosts are deposited and registered in repository of the Estuarine Biological Research Centre (EBRC), Zoological Survey of India (ZSI), Gopalpur-on-Sea, Odisha, India. Molecular identification and its characterization of these isopod parasites were carried out based on the COI gene sequence. DNA isolation from the isopod tissue samples was done by using the EX pure Tissue DNA isolation kit developed by Bogar Bio Bee stores Pvt Ltd. PCR amplification and next generation sequencing using oxford nanopore sequencing platform were carried out as per the description of Seth et al. (2019) and Cuscó et al. (2019). Especially $650-700$ base pair of the full COI gene was targeted for amplification and sequencing purpose. 
For both PCR amplification and sequencing of the COI gene, the universal LCO 1490: 5'ggtcaacaaatcataaagatattgg-3' and HCO 2198: 5'- taaacttcagggtgaccaaaaaatca-3' primers set were used. The PCR reaction mixture $(25 \mu \mathrm{L})$ for COI gene was composed of isolated DNA $(5 \mu \mathrm{L})$, forward primer $(1.5$ $\mu \mathrm{L})$ and reverse primer (1.5 $\mu \mathrm{L}$ of), molecular grade deionised water $(5 \mu \mathrm{L})$, and Taq Master Mix $(12 \mu \mathrm{L})$. The PCR thermal regime was done by setting an initial denaturation step for the duration of 4 minutes at $95^{\circ} \mathrm{C}$, followed by 34 cycles for the duration of 45 second at $95^{\circ} \mathrm{C}, 30$ second at $40^{\circ} \mathrm{C}$ annealing temperature, 50 second at $72^{\circ} \mathrm{C}$ for the extension step, and for 10 minutes at $72^{\circ} \mathrm{C}$ for the final step, followed by indefinite hold at $4^{\circ} \mathrm{C}$. The sequences were assembled by using Macvector 16.0.10. The obtained sequences were checked in the NCBI blast tool for similarity checking. The final sequences were submitted to NCBI to get the accession numbers. The accession number obtained from the NCBI for the submitted $\mathrm{COI}$ gene sequence of the parasites with 5th pereonite smaller (gravid female) and bigger (intermoult female) are MK672880 (number of base pair: 657) and MK672881 (number of base pair: 681) respectively.

For multiple sequences alignment, pair wise K2P distance and ML using Kimuara-2-parameter model (Kimura 1980) for COI genes between the species L. typus and other species of the buccal attaching genera under the family Cymothoidae were carried through MEGA 10 (Kumar et al. 2018). We obtained available COI gene sequences from different database for the genera: Glossobius and Cinusa, but unable to retrieve any sequence for the genus: Smenipsa. Bootstrap analysis (Felsenstein 1985) was carried out to verify the robustness of the internal nodes in the evolutionary tree using 1000 replications.

\section{Results}

Cymothoidae parasites collected from the buccal region of different individuals of the same host fish $T$. lepturus, belong to same species L. typus; and are having brood pouch, so they belongs to same sex i.e. female. The parasites along with the host are shown in the figure 1.These parasites are in different stages of moulting and can be distinguished into two morphologies based on the size of the $5^{\text {th }}$ pereonite (in terms of length of $5^{\text {th }}$ pereonite to total body length percentage). The length of the $5^{\text {th }}$ pereonite to total body length is $4.5-4.76 \%$ in the four individuals having smaller $5^{\text {th }}$ pereonite (gravid female) vs $7.7-7.81 \%$ in the four other individuals having bigger $5^{\text {th }}$ pereonite (intermoult female). There is also difference in pleon to total body length comparison between these two morphologies. Pleon to body length percentage is comparatively larger in gravid female (28.18-30.43\% vs $23.49-26.01 \%)$. The diagnostic features of the parasites are as per the description of Yu and Bruce (2006) and Rabichandran et al. (2019). The morphometric measurements of theses parasites are provided in table 1. Taxonomic account of the isopod parasites are given below:

Order. Isopoda Latreille, 1817

Family: Cymothoidae, 1818

Genus: Lobothorax Bleeker, 1857 
Type species and type locality: Lobothorax typus Bleeker, 1857; by monotypy, collected from Jakarta, Java, Indonesia (Rabichandran et al. 2019).

Diagnosis: The detailed identifying features and description of this isopod was provided by Yu and Bruce (2006) and Rabichandran et al. (2019).

Description: Number of materials examined: 08. Registration number: EBRC/ZSI/Cr-110911 A-D (04 examples, $5^{\text {th }}$ pereonite smaller, gravid female) and Registration number: EBRC/ZSI/Cr-11090 A-D (04 examples, $5^{\text {th }}$ pereonite bigger, intermoult female). Body of the parasite is straight. Pereon is having middorsal longitudinal ridge, cephalon is triangular, and eyes are distinct and moderate in size. Pereonite $1^{\text {st }}$ is the longest one and having expanded anterolateral process. Pereonites 2-4 are almost equal in length and distinctly shorter than the $1^{\text {st }}$ one. Pereonites 5-7 are distinctly shorter then 1-4. Pereonite $5^{\text {th }}$ is overlapped partly by the $4^{\text {th }}$ pereonite. All pleonites are visible and sub-equal in length. The Pleonite 1 is narrow and partly overlapped by the pereonite 7. Pleonites 2-5 are gradually wider. The Pleotelson is subrectangular in shape and its posterior margin tapering to caudomedial point. The antennule is slightly shorter than antenna. The antennule is robust and consisting of 8 articles, the antenna is slender and consisting of 9 articles. The colour of body is whitish and there is presence of black and green chromatophores on the pleon region (Fig. 1).

Gravid female: It is about 2.54-2.69 times as long as wide (at $5^{\text {th }}$ pereonite). $5^{\text {th }}$ pereonite is distcintly smaller in terms of length as compared to the $6^{\text {th }}$ and $7^{\text {th }}$ pereonite. The length of the $5^{\text {th }}$ pereonite is about $4.5-4.76 \%$ percentage of total body length. Pleon is short; it is about $28.18-31.28 \%$ of the total body length. The pleotelson is about 1.50-2.25 times as long as the wide. (Table 1; Fig. 1: b1 and b2)

Intermoult Female: It is about 2.15-2.98 times as long as wide (at $5^{\text {th }}$ pereonite). $5^{\text {th }}$ pereonite is distcintly bigger in terms of length as comapared to the $6^{\text {th }}$ and $7^{\text {th }}$ pereonite. The length of the $5^{\text {th }}$ pereonite is about 7.7-7.81 percentage of total body length. Pleon is short; it is about 23.49-27.07 percentage of the total body length. Pleotelson is about 1.6-2.01 times as long as the wide. (Table 1; Fig. 1: $\mathrm{c} 1$ and c2).

The COI gene of the L. typus is rich with AT nucleotides. The AT nucleotides percentage is about $63.51 \%$. There is no difference in the K2P distance between the COI gene sequences of $L$. typus. The K2P distance between L. typus and species of the genus Cymothoa is $24-28 \%$, between L. typus and species of the genus Ceratothoa is $30-34 \%$, between L. typus and Glossobius auritus is $30-31 \%$ and between L. typus and Cinusa tetrodontis is $29-30 \%$. The K2P distance between the genus Cymothoa and Ceratothoa is $26-33 \%$, between Cymothoa and G. auritus is $28-30 \%$ and between Cymothoa and C. tetrodontis is $28-30 \%$. The K2P distance between genus Ceratothoa and G. auritus is $26-30 \%$ and between Ceratothoa and $C$. tetrodontis is $26 \%$. The K2P distance between $G$. auritus and $C$. tetrodontis is $27 \%$ (Table 2).

In the ML tree analysis: all the three $\mathrm{COI}$ gene sequences of $L$. typus belong to the same clade with a strong bootstrap value of $100 \%$. All the buccal attaching genera: Ceratothoa, Cinusa, Cymothoa, and Lobothorax are monophyletic with bootstrap support of moderate to strong. Representative considered under the genus Cymothoa belongs to same clade with a strong bootstrap support of $71 \%$, representatives of the genus 
Ceratothoa belongs to same clade with a strong bootstrap support of $76 \%$, single sequence of genera Cinusa and Glossobius are separted with moderate boostrap value of $58 \%$ and $36 \%$ respectively (Fig. 2).

\section{Discussion And Conclusion}

The specimens of L. typus well matched with the description provided by Yu and Bruce (2006) and Rabichandran et al. (2019). The present finding of the isopod parasites L. typus from the buccal region of the host fish species T. lepturus from coastal Goaplpur-on-Sea extends its geographical range and is the first material evidence for the state of Odisha, India. The differences observed in the 5th pereonite in terms of its length and pleon to body length percentage of the two morphologies of the parasites; which are not showing any difference in other morphological features, in the K2P distance, $\mathrm{COI}$ gene sequence and belonging to same cluster in $M L$ tree analysis; confirms the biphasic moulting in cymothoid isopod $L$. typus. This observation is the first material evidence of the biphasic moulting in this parasite. A long term study on the life cycle of this parasite will provide better understanding of its biology.

The Systematic study of the species of the family cymothoidae is tricky when only the data from the morphological features are available because sometimes intra-specific variation is adequately larger than the inter-specific variation. As a result of which phylogeny which is only based on morphological data may be confusing and misleading. Therefore, molecular marker like $16 \mathrm{~s}$ rRNA and COI gene sequences can be very useful in resolving the phylogeny of the species of the family cymothoidae (Hata et al. 2017). The present molecular characterization of COI gene of L. typus, will be useful for resolving the intra and inter specific variation encounter during the further study of the life cycle of this parasite. The present report of the monophyletic phylogeny of the buccal attaching isopods of the family cymothoidae is in congruence with their morphological divergence (Martin 2025; Hata et al., 2017). However, for a better understanding of the molecular systematics and phylogeny of the buccal attaching cymothoidae; more molecular data especially of the COI genes of the genera: Cinusa, Glossobius and Smenipsa need to be carried out.

\section{Declarations}

\section{Acknowledgements}

The authors are thankful to the Head, P. G. Department of Zoology, Berhampur University for providing laboratories facilities. The authors are also thankful to the Director, Zoological Survey of India, Kolkata for providing facilities.

\section{Conflict of interest statements}

Authors declare that they have no conflict of interest.

\section{References}

1. Aneesh PT, Helna AK, Trills JP, Chandra K (2019) Occurrence and redescription of Anilocra leptosome Bleeker, 1857 (Crustacea: isopoda: Cymothoidae) parasitizing the clupeid fish Tenualosatoli 
(Valenciennes) from the Arabian Sea, India. Mar Biodivers 49 (1):443-450. doi:10.1007/s12526-0170828-7.

2. Aneesh PT, Helna AK, Trills JP, Chandra KA (2018) Taxonomic review of the genus Joryma Bowman and Tareen, 1983 (Crustacea: Isopoda: Cymothoidae) parasitizing the marine fishes from Indian waters, with a description of a new species, Mar Biodivers 49:1449-1478. https://doi.org/10.1007/s12526-018-0920-7.

3. Aneesh PT, Kappalli S (2020) Occurrence of Life Cycle Dependent Monophasic and Biphasic Molting in a Parasitic Isopod, Mothocya renardi. Thalassas https://doi.org/10.1007/s41208-019-00188-6

4. Bruce NL (1981) Redescription of the isopod (Crustacea) family Phoratopodidae. Beaufortia 31:107-110.

5. Cuscó A, Catozz C, Viñes J, Sanchez A, Francino O (2019) Microbiota profiling with long amplicons using Nanopore sequencing: full-length 16S rRNA gene and the 16S-ITS-23S of the rrn operon. F1000Research, 7: 1755 .https://doi.org/10.12688/f1000research.16817.2.

6. Felsenstein J (1985) Confidence limits on phylogenies: An approach using the bootstrap.Evolution 39:783-791

7. Froese R, Pauly D (2018) Fishbase, version (06/2018), world wide web electronic publication. http:// fishbase.org. (Accessed during December, 2018).

8. Hata H, Sogabe A, Tada S, Nishimoto R, Nakano R, Kohya N, Takeshima H, Kawanishi R (2017) Molecular phylogeny of obligate fsh parasites of the family Cymothoidae (Isopoda, Crustacea): evolution of the attachment mode to host fsh and the habitat shift from saline water to freshwater. Mar Biol. DOI 10.1007/s00227-017-3138-5.

9. Kimura M (1980) A simple method for estimating evolutionary rate of base substitutions through comparative studies of nucleotide sequences.J Mol Evol 16:111-120

10. Kumar AA, Rameshkumar G, Ravichandran S, Priya ER, Nagarajan R, Leng, AGK (2015) Occurrences of cymothoid isopod from Miri, East Malaysian marine fishes. J Parasit Dis 39(2): 206-210. doi: 10.1007/s12639-013-0320-7

11. Kumar S, Stecher G, Li M, Knyaz C, Tamura K (2018) MEGA X: Molecular Evolutionary Genetics Analysis across computing platforms. J Mol Evol 35:1547-1549.

12. Martin MB (2015) Taxonomy and phylogeny of the buccal-attaching Cymothoidae (Crustacea: Isopoda) of Australia. Dissertation, University of Tasmania.

13. Rameshkumar G, Ravichandran S, Sivasubramanian K, Trilles, JP (2013) New occurrence of parasitic isopods from Indian fishes. J Parasit Dis 37(1): 42-46. doi: 10.1007/s12639-012-0128-x.

14. Raupach MJ, Barco A, Steinke D, Beermann J, Laakmann S, Mohrbeck I, Neumann H, Kihara TC, Pointner K, Radulovici A, Segelken-Voigt A, Wesse C, Knebelsberger T (2015) The Application of DNA Barcodes for the Identification of Marine Crustaceans from the North Sea and Adjacent Regions. PLoS ONE 10(9): doi:10.1371/journal.pone.0139421

15. Ravichandran S, Vigneshwaran P, Rameshkumar G (2019) A taxonomic review of the fish parasitic isopod family Cymothoidae Leach, 1818 (Crustacea: Isopoda: Cymothooidea) of India. Zootaxa 4622 
(1): 001-099. https://doi.org/10.11646/zootaxa.4622.1.1

16. Richardson H (1910) Marine isopods collected in the Philippines by the U.S. Fisheries steamer Albatross in 1907-08. Bureau of Fisheries Document 736: 1-44

17. Sahadevan AV, Jose Priya TA and Kappalli S (2019) Biphasic moult cycle of the parasitic isopod Norileca indica (H. Milne Edwards, 1840) (Isopoda: Cymothoidea):

stage-wise characterisation and haemolymph ecdysteroids titre. J Crust Biol 1-10. doi:10.1093/jcbiol/ruz082.

18. Schiöedte JC, Meinert F (1881) Symbolæ ad monographium Cymothoarum crustaceorum isopodum familiæ. Anilocridæ. Naturhistorisk Tidsskrift. 12: 1- 166.

19. Seth JK, Behera AK, Mohanty SR, Mohapatra A (2020) Extension of host range for Anilocra dimidiata, Nerocila sigani and first record of Nerocila depressa (Isopod: Cymothiod)from Odisha coast, India. Indian J Geo-Mar Sci 49(8):1498-1500.

20. Seth JK, Chakraborty S, Roy S, Mohapatra A (2020) New host record of Joryma malabaricus, Joryma hilsae and first record of Joryma sawayah (Isopoda: Cymothoidae) from Odisha coast, India. Indian J Geo-Mar Sci.49(8):1501-1504.

21. Seth JK, Mohapatra SK, Mishra P, Behera R, Lingam D (2019) Native Species Displacement by Invasive Alien Species Yellow Crazy Ant: Anoplolepis gracilipes (Smith 1857) (Hymenoptera: Formicidae). Indian J Ecol 46(4): 867-870

22. Smit NJ, Bruce NL, Hadfield KA (2014) Global diversity of fish parasitic isopod of the family Cymothoidae. Int. J. Parasitol. Parasites wildl 3:188197.http://dx.doi.org/10.1016/j.jppaw.2014.03.004

23. Yu HY, Bruce NL (2006) Redescription of Lobothorax typus, Bleeker, 1857 (Isopoda, cymothoidae): the first record of the species and genus from Chinese waters. Crustaceana 79(6):641-648.

\section{Tables}

Table 1: Morphometric measurements of L. typus 


\begin{tabular}{|c|c|c|c|c|c|c|c|}
\hline \multicolumn{2}{|c|}{ SI. No. } & \multirow{2}{*}{$\begin{array}{l}\text { Total Length } \\
\text { of Body in mm } \\
\text { (Head to } \\
\text { Pletelson) } \\
\\
22.51\end{array}$} & \multirow{2}{*}{$\begin{array}{l}\begin{array}{l}\text { Width of } \\
\text { Body in } \\
\text { mm (At } 5^{\text {th }} \\
\text { Pereonite) }\end{array} \\
8.34\end{array}$} & \multirow{2}{*}{$\begin{array}{l}\text { Length of } \\
\text { Pleotelson } \\
\text { in } \mathrm{mm}\end{array}$} & \multirow{2}{*}{$\begin{array}{l}\text { Width of } \\
\text { Pleotelson } \\
\text { in } \mathrm{mm}\end{array}$} & \multirow{2}{*}{$\begin{array}{l}\text { Length of } \\
\text { Pleon in } \\
\text { mm } \\
\text { (Pleonites } \\
\text { to } \\
\text { Pleotelson) } \\
6.85\end{array}$} & \multirow{2}{*}{ 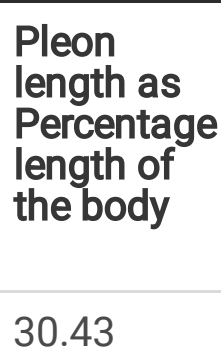 } \\
\hline 1 & Gravid & & & & & & \\
\hline 2 & & 18.31 & 7.08 & 2.79 & 5.60 & 5.16 & 28.18 \\
\hline 3 & & 18.09 & 6.71 & 2.41 & 5.43 & 5.19 & 28.68 \\
\hline 4 & & 16.59 & 6.51 & 3.00 & 4.75 & 5.19 & 31.28 \\
\hline 5 & \multirow{4}{*}{$\begin{array}{l}\text { Inter- } \\
\text { moult } \\
\text { female }\end{array}$} & 16.22 & 7.52 & 2.97 & 5.45 & 4.22 & 26.01 \\
\hline 6 & & 15.96 & 5.78 & 2.12 & 4.27 & 3.75 & 23.49 \\
\hline 7 & & 16.62 & 6.00 & 2.23 & 4.46 & 4.50 & 27.07 \\
\hline 8 & & 20.48 & 6.87 & 2.79 & 4.88 & 5.24 & 25.58 \\
\hline
\end{tabular}

Table 2: Kimura 2 parameter distance (K2P) matrix in percentage 


\begin{tabular}{|c|c|c|c|c|c|c|c|c|c|c|c|c|c|c|c|}
\hline & $\begin{array}{l}\text { Sp. } \\
\text {. }\end{array}$ & $\begin{array}{l}\text { Sp. } \\
\text {. }\end{array}$ & ${ }_{3}^{\text {Sp. }}$ & $\begin{array}{l}\text { Sp. } \\
4\end{array}$ & $\begin{array}{l}\text { Sp. } \\
5\end{array}$ & $\begin{array}{l}\text { Sp. } \\
6\end{array}$ & $\begin{array}{l}\text { Sp. } \\
7\end{array}$ & $\begin{array}{l}\text { Sp. } \\
8\end{array}$ & $\begin{array}{l}\text { Sp. } \\
9\end{array}$ & $\begin{array}{l}\text { Sp. } \\
10\end{array}$ & $\begin{array}{l}\text { Sp. } \\
11\end{array}$ & $\begin{array}{l}\text { Sp. } \\
12\end{array}$ & $\begin{array}{l}\text { Sp. } \\
13\end{array}$ & $\begin{array}{l}\text { Sp. } \\
14\end{array}$ & $\begin{array}{l}\text { Sp. } \\
15\end{array}$ \\
\hline $\begin{array}{l}\text { Sp. } \\
1\end{array}$ & & & & & & & & & & & & & & & \\
\hline${ }_{2}^{\text {Sp. }}$ & 0 & & & & & & & & & & & & & & \\
\hline $\begin{array}{l}\text { Sp. } \\
3\end{array}$ & 0 & 0 & & & & & & & & & & & & & \\
\hline $\begin{array}{l}\text { Sp. } \\
4\end{array}$ & 28 & 27 & 27 & & & & & & & & & & & & \\
\hline $\begin{array}{l}\text { Sp. } \\
5\end{array}$ & 28 & 27 & 27 & 0 & & & & & & & & & & & \\
\hline $\begin{array}{l}\text { Sp. } \\
6\end{array}$ & 24 & 24 & 24 & 20 & 20 & & & & & & & & & & \\
\hline $\begin{array}{l}\text { Sp. } \\
7\end{array}$ & 25 & 25 & 25 & 20 & 20 & 0.5 & & & & & & & & & \\
\hline $\begin{array}{l}\text { Sp. } \\
8\end{array}$ & 27 & 26 & 25 & 0.3 & 0 & 19 & 20 & & & & & & & & \\
\hline $\begin{array}{l}\text { Sp. } \\
9\end{array}$ & 28 & 28 & 28 & 0.3 & 0 & 19 & 20 & 0 & & & & & & & \\
\hline $\begin{array}{l}\text { Sp. } \\
10\end{array}$ & 27 & 27 & 26 & 5 & 5 & 20 & 20 & 5 & 5 & & & & & & \\
\hline $\begin{array}{l}\text { Sp. } \\
11\end{array}$ & 34 & 34 & 34 & 28 & 27 & 33 & 33 & 27 & 27 & 29 & & & & & \\
\hline $\begin{array}{l}\text { Sp. } \\
12\end{array}$ & 34 & 34 & 34 & 28 & 27 & 33 & 33 & 27 & 27 & 29 & 0 & & & & \\
\hline $\begin{array}{l}\text { Sp. } \\
13\end{array}$ & 31 & 30 & 30 & 28 & 27 & 29 & 29 & 26 & 27 & 27 & 22 & 22 & & & \\
\hline $\begin{array}{l}\text { Sp. } \\
14\end{array}$ & 31 & 31 & 30 & 30 & 30 & 33 & 33 & 28 & 30 & 29 & 30 & 30 & 26 & & \\
\hline $\begin{array}{l}\text { Sp. } \\
15\end{array}$ & 30 & 29 & 29 & 30 & 29 & 32 & 32 & 28 & 30 & 29 & 26 & 26 & 26 & 27 & \\
\hline
\end{tabular}

Note: Sp. 1-2: Lobothorax typus, Sp. 3: Lobothorax sp., Sp. 4-5: Cymothoa eremite, Sp. 6-7: Cymothoa excise, Sp. 8-9: Cymothoa pulchrum, Sp. 10: Cymothoa indica, Sp. 11-12: Ceratothoa oestroides, Sp. 13: Ceratothoa carinata, Sp. 14: Glossobius auritus, Sp. 15: Cinusa tetrodontis

\section{Figures}




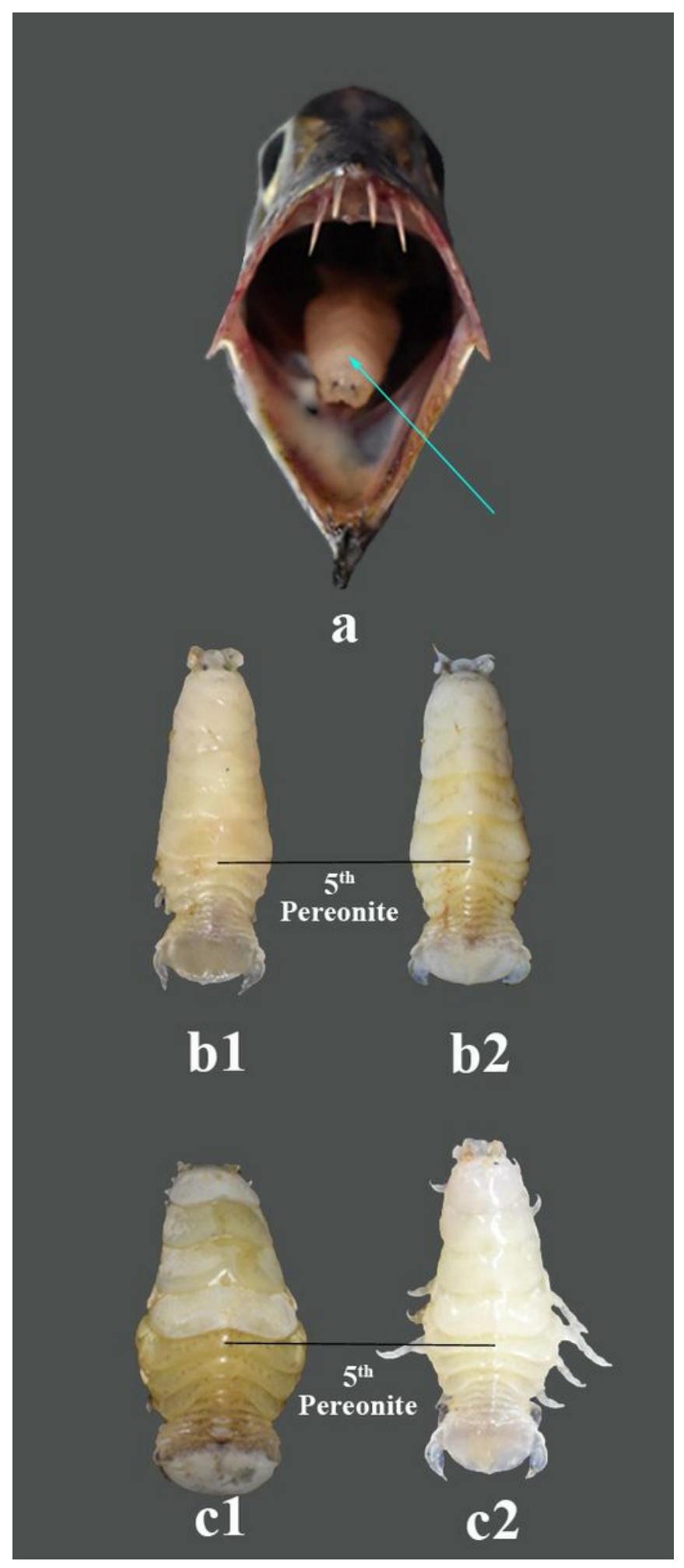

Figure 1

a: L.typus inside the buccal cavity of T. lepturus; b1 and b2: L.typus (Gravid Female); c1 and c2: L.typus (Intermoult female) 


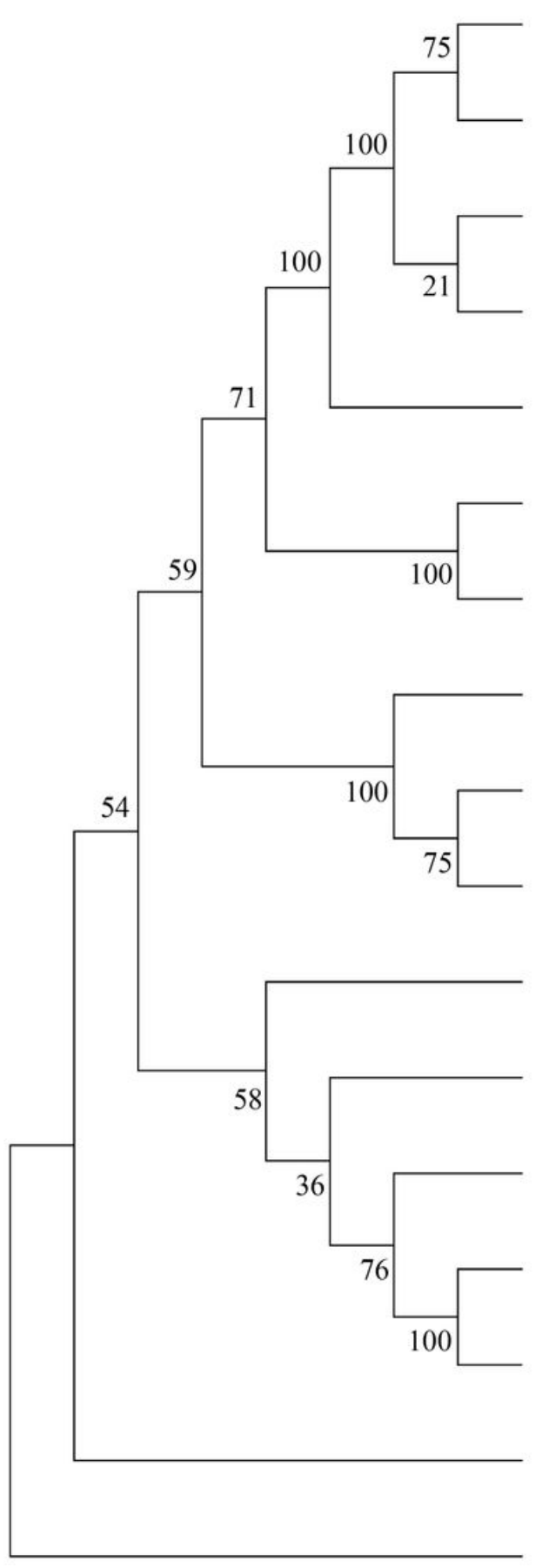

MK430025.1 Cymothoa eremita (Malaysia)

MK430022.1 Cymothoa eremita (Malaysia)

LC160322.1 Cymothoa pulchrum (Japan)

LC160321.1 Cymothoa pulchrum (Japan)

Cymothoa Clade

MH396438.1 Cymothoa indica (China)

KP339865.1 Cymothoa excisa (USA)

KP339866.1 Cymothoa excisa (USA)

MK672880.1 Lobothorax typus

(Present study, Odisha, India)

MK672881.1 Lobothorax typus

Lobothorax Clade

(Present study, Odisha, India)

LC159571.1 Lobothorax sp. (Japan)

MK652480.1 Cinusa tetrodontis (UK)

LC159569.1 Glossobius auritus (Japan)

MK652479.1 Ceratothoa carinata (UK)

GQ240280.1 Ceratothoa oestroides (Croatia)

Ceratothoa Clade

GQ240279.1 Ceratothoa oestroides (Croatia) -

AF260841.1 Excirolana chiltoni

KT122554.1 Excirolana chiltoni

Outgroup

\section{Figure 2}

Maximum likelihood (ML) tree based on COI gene sequences of the buccal attaching cymothoidae 